\title{
Introduction: Relations and the Historiography of Medieval Philosophy
}

This is the first special issue of the British Journal of the History of Philosophy to be devoted to the thought of the Middle Ages. Its topic is relations. The articles have been chosen to give an idea of the range of the broadly medieval traditions - in Greek and Arabic, as well as Latin, from the eighth until the seventeenth century. Most of the contributions concern the metaphysics of relations, but the logic of arguments involving relations is also considered, as well how ideas about relations are used to address other philosophical or theological issues. The main purpose of this introduction is to sketch out the wider background into which each of the following specialized discussions fits, looking in turn at the general doctrinal background, the methodological background and then at the more particular contexts of each of the papers. It concludes with some suggestions about the direction and methods of future research.

For a fuller survey of the area, readers can turn to a number of general studies written over the last fifty years. In the 1960s, Julius Weinberg set out briefly the whole history of discussions about relations, concentrating especially on 'medieval views'. ${ }^{1}$ Mark Henninger's Relations. Medieval Theories 1250-1325 (1989) is both narrower, as the title makes clear, and far more detailed, setting out with analytical clarity the complex theories of Aquinas, Henry of Ghent, Richard of Middleton, Duns Scotus, Henry of Harclay, William of Ockham and Peter Aureoli. Henninger is criticized for his restricted range by Rolf Schönberger, whose monograph on relations in Buridan contains a book-length survey of the earlier Latin tradition, starting with Aquinas and covering many writers not examined by Henninger, including Siger of Brabant, Dietrich of Freiberg, Meister Eckhart, Jacob of Viterbo, Peter John Olivi, John of Jandun and others (63-236). Two short surveys provide an even greater range, but with much less detail: Burkhard Mojsisch in the Historisches Wörterbuch der Philosophie and Laurent Cesalli in the Dictionnaire du Moyen Âge. The encyclopedia entry, however, which is most likely to provide Anglophone readers with an introduction to the subject is Jeffrey Brower's contribution ('Medieval Theories of Relations') to the online Stanford Encyclopedia of Philosophy, an extended essay that takes a very different approach to Mojsisch and Cesalli, going light on the details of different thinkers and their precise theories in order to give a sophisticated exposition, in the terms of contemporary philosophy, of what he considers the main theoretical options developed by the 'medievals' (twelfth to early fourteenth-century Latin thinkers). More detail can be found in the 2013 issue of Quaestio, edited by Pasquale Porro and Vincent Carraud, devoted to 'The Ontology of Relation', which contains specialized studies of Alhazen and Avicenna, Scotus, Auriol, Dietrich of Freiberg, Burley and Ockham. Finally, all but two of the articles printed here are based on papers given at the twentieth European Symposium of Medieval Logic and

\footnotetext{
${ }^{1}$ Abstraction, Relation, and Induction, 61-119. The section on the Middle Ages, which includes some discussion of Greek patristic and Arabic theories, is at 86-112.
} 
Semantics in June 2014, on 'Medieval Theories of Relations', but they represent only a small selection from over thirty contributions. The papers ranged widely over - and beyond - the subject. A summary of them has been published, and most of them will in due course be collected into a book. ${ }^{2}$

\section{The doctrinal background}

Aristotle is the starting point for almost all medieval discussion of relations. Yet, although his texts on it - especially Categories Chapter 7, available from early on in all the traditions, Metaphysics V, 15 and Physics V,2 (225b11-13)- were relentlessly glossed, the question was shaped less by them in particular than by Aristotle's more general metaphysical framework. In the specific texts themselves, Aristotle talks, not about relations (such as being greater than, or being the father of), but about things taken under the description of being related (such as a number, which is a quantity, greater than another, or a man, who is his son's father). ${ }^{3}$ The ontology of the Categories, however, divided all things into substances particular members of natural kinds, such as a human, a horse or a flower - and their accidents, particular properties of a substance which it can gain and lose without ceasing to be the sort of substance it is - Socrates's whiteness and his being-six-foot-tall, for example. Particular accidents cannot exist independently, and each is considered to belong to just one particular substance. (According to many medieval interpreters of Aristotle, there are also universal substances and accidents. Some disagreed, but, in any case, discussion about relations focused on particulars.)

On this Aristotelian scheme a relation, such as Socrates's being taller than Plato, or Abelard's being the father of Astrolabe, is a particular accident. As such, it was usually accepted that it belongs to just one substance: 'being taller than Plato' is an accident of Socrates, not of Plato, although, unlike Socrates's whiteness or being-six-foot-tall, it looks towards or regards something else - Plato. According to the terminology which became standard in the universities of later medieval Latin Europe, Socrates is the 'subject' of a (particular) relation of being taller than, and Plato is the 'term' of this relation, which has as its 'foundation' Socrates's accident, in the Aristotelian category of quantity, of being-sixfoot-tall. If Socrates is taller than Plato, then Plato will be shorter than Socrates, and so there will also be a particular relation of being shorter than Socrates in Plato as its subject and with his being-five-foot tall as its foundation.

Medieval discussion of relations concerned especially their ontological status within this framework. There seems to be good reason to query whether relations are items in their own right, and Aristotle himself describes them as being even less substances or things than any other of the categories (Metaphysics XIV.1, 1088a23, 30). For Socrates to be taller than

\footnotetext{
${ }^{2}$ Marenbon and Strobino, 'Congrès terminés'. Riccardo Strobino will be the editor of the conference proceedings.

${ }^{3}$ See below, Martin, 'The Invention of Relations', pp. XXX-XXX, where there is a careful analysis of the whole passage from the Categories. For a more detailed recent discussion, see Allen Bäck, Aristotle's Theory of Abstraction, 29-44.
} 
Plato, is any further entity needed beyond Socrates's being-six-foot-tall and Plato's beingfive-foot-tall? Medieval philosophers saw the point clearly. Most of them held, none the less, that such further entities are needed, but found various ways to qualify the extent to which they are separate beings; a few ruled them out altogether.

Although Aristotle provided the framework, religious dogma also helped to mould medieval treatment of relations. The influence of Christianity, in particular, is especially evident. Not only did Christians, like Muslims and Jews, have to consider the relation between an immutable God and his changeable creatures; they also had to explain how there can be relations (of fatherhood, sonship and being spirated) in God himself. Aristotle's idea (Categories $7 \mathrm{~b} 22-8 \mathrm{a} 12$ ) that there are one-sided relations between, for instance, knowledge and the knowable was developed into the theory that, whereas creatures have real relations to God, God is related to them only by reason. The fact of there being relations in God entailed a departure from Aristotle, because these relations could not be accidents, since there are no accidents in God. Moreover, since it was heretical to hold that Trinitarian relations are merely ways of conceiving God, the doctrine of the Trinity - as Suarez, looking back at the whole tradition, put it - gave 'great probability' to the position that there are real relations in creatures, since it shows that 'the concept of relation as such ... is not a fiction ... but is something real, since in God it is something real.' (Disputatio Metaphysica 47, 1, 11; Suarez, Disputationes, II, 784)

\section{The Methodological Background}

Medieval treatments of relations differ from twentieth and twenty-first century ones, at least in analytic philosophy, in one striking way. Since the time of Frege and Russell, most philosophers have agreed that relations are polyadic (many-placed) properties. Whereas a property such as whiteness is one-placed, because it can be represented by a one-place function ( $W x)$ or expressed by a sentence with one blank space ('--- is white'), 'taller than' is said to be a two-placed property, because it is represented by a two-place function (Txy) or expressed by a sentence with two blank spaces ('--- is taller than---'). Almost all medieval theories of relations, however, as explained above, consider them to be accidents in a single subject - that is to say, in contemporary terms, as monadic properties. ${ }^{4}$ Although medieval authors certainly acknowledge that a relation 'looks to' something else, it inheres in just one of the related things.

When, nearly seventy years ago, A. Krempel wrote what remains the most detailed study of any single medieval author's theory of relations (La doctrine de relation chez Saint Thomas), he seemed entirely unaware of such a difference. Although he says that he is not merely concerned to reconstruct the view of his chosen author, but with finding the truth, his range of reference remains within the scholastic tradition, with the occasional glance at Kant. Julius Weinberg's approach, a decade later, could hardly have been more different. In his

\footnotetext{
${ }^{4}$ For the 'almost', see below, nn. 8 and 9.
} 
view, the ancient and medieval understanding of relations is simply incorrect, because relations are taken (63) 'as a special variety of accidents'. 'The various substance ontologies of the past', he believes (63), 'have prevented or retarded an adequate theory of relations', as 'a feature of facts which involves two terms taken together' (119). But Weinberg's overriding concern to see medieval theories in the light of contemporary approaches has not been widely followed. Schönberger, in the mid-1990s, is dimly aware of Russell's views about relations and discussions in that tradition, but does not let them affect his approach. The encyclopaedic surveys in German and French stick firmly to the medieval conception of their topic. ${ }^{5}$

This is not, as might be suspected, a division between Anglophone analytic approaches, and those of scholars trained in Continental Europe. Henninger, an American scholar, emphasizes and explains the 'strangeness' which 'most find in medieval theories of relation' at the very beginning of his study: -

Today we might talk of one symmetrical relation $\mathrm{R}$ of colour similarity between two pieces of white chalk, $a$ and $b$. But for the medieval, if there are two really distinct substances, there must be two really distinct accidents. (4)

But in what follows he aims simply to set out the various medieval theories in their own terms. In this approach, he is following his teacher, Marilyn McCord Adams. She distinguishes and separates the contemporary from the medieval view, not without some tartness towards the former. ${ }^{6}$ The approach taken by Adams and Henninger has been that of most scholars, wherever trained, who have looked at one or another medieval philosopher's theory of relations; so that it might be called the 'Normal Historical Method'. Even writers such as Peter King, who are known for their analytic training and acumen evince them, like Adams and Henninger, by their clarity in presenting the different aspects of the medieval discussions rather than in making links or contrasts with contemporary debates. ${ }^{7}$

Within the ambit of Normal Historical Method, however, writers may give more or less incidental attention to contemporary treatments of the theme they are studying. One example is Sten Ebbesen. He believes that 'many of the problems the medieval incurred may be said to be due to their persistent attempts to squeeze polyadic predicates into moulds made for monadic ones', but, as well as showing the links between medieval theories of signification and of relations, he brings to light a thirteenth-century discussion which, against the usual medieval grain, treats a binary relation as applying to a pair of objects, and not to each one singly. ${ }^{8}$ More recently, Heine Hansen has shown that Ebbesen's suspicion that the

\footnotetext{
${ }^{5}$ These are the entries by Mojsisch and Cesalli mentioned above; Cesalli, it should be noted, is also an expert on late-nineteenth and early twentieth-century philosophy, and so anything but a stranger to post-medieval views about relations.

${ }^{6}$ Adams, William Ockham, 216: 'The appeal of identifying real relations with things really distinct from absolute things might seem obvious. If relations were real things, they could serve as a kind of metaphysical glue, sticking real things together by inhering in both of them at once. While medieval did assign real relations a unifying function, they would have rejected the latter development of the thesis as impossible.'

${ }^{7}$ See, for instance, Peter King on Scotus' theory in 'Scotus on Metaphysics', 33-38.

8 'Tantum Unum Est', 183-84.
} 
theory was not confined to a single text is well founded. ${ }^{9}$ Jeffrey Brower is aware of these discoveries, but he looks at the problem from a rather different angle. 'Medieval philosophers', he insists,

approach the issue in the same basic way that contemporary philosophers do. Indeed, like us, they have a clear understanding of polyadic predicates, and they rely on them for their understanding of relations. ${ }^{10}$

But, he explains, a few exceptional authors apart, no one in the period would accept that there can be polyadic properties to correspond to these terms. Whilst a minority reaction, as found in Peter Aureol, was to deny the reality of relations altogether, most thinkers accepted real relations, and either, reductively, identified them with monadic properties on which they are founded (for instance, Socrates's being-six-foot-tall) or, non-reductively, characterized them as sui generis monadic properties. Following this line of thought, Sydney Penner ('Why did Medieval Philosophers Reject Polyadic Accidents?') has sought out and scrutinized the quite rare cases where medieval philosophers do not simply assume the rejection of polyadic accidents, but make arguments to justify it. ${ }^{11}$

\section{The Articles in this Special Issue}

The title of this special issue refers to medieval traditions. The plural is important, although it might perhaps be more accurate to speak of different branches of the same tradition. Medieval philosophy grows from late ancient thought, in different parallel and sometimes interconnected branches or traditions, within different cultures: the four most important are Greek (Byzantine) Philosophy, Latin Philosophy, Arabic Philosophy and Jewish Philosophy (in Arabic and Hebrew). ${ }^{12}$ Narrowness of vision - and the lack of philosophical scholars trained in Arabic and Hebrew - has led to an overwhelming emphasis on the Latin tradition among those writing about relations; the general accounts discussed above confine themselves almost entirely to it. The articles collected here do not achieve a balance, but they do at least include contributions on the Greek (Byzantine) and Arabic traditions.

Christophe Erismann focuses on a particular way in which Aristotle's discussions of relatives was put to use in the controversy over the worship of icons which split Byzantium in the eighth and ninth centuries. An image and its model are a pair of relatives, whereas, by contrast - as the Byzantine iconophiles wished to stress - an idol is not a relative, because it

\footnotetext{
9 'Strange Finds'; cf. Ebbesen, 'The Paris Arts Faculty', p. 271. See also Penner, 'Why did Medieval Philosophers Reject Polyadic Accidents?', n. 20.

10 'Aristotelian vs Contemporary Perspectives', 40. The same ideas are put forward in his 'Relations'; he began to develop these views in 'Abelard's Theory of Relations'.

11 'Why did Medieval Philosophers Reject Polyadic Accidents?'

${ }^{12}$ For a short presentation of why, in general, medieval philosophy should be approached in its different Latin, Greek, Arabic and Hebrew manifestations, see Marenbon, Medieval Philosophy, esp. 1-43.
} 
has no real model to which it can be related. But there is an obvious problem. According to Aristotle, relatives must be 'simultaneous by nature': that is to say, if A and B are relatives, then A cannot exist if B does not exist, and B cannot exist if A does not exist. Most icons, however, depict figures who are now dead, even if in some cases they were alive when the icon was made. According to Erismann, one way round the difficulty, proposed by Theodore Studite, is to say that a figure - he gives Christ as his example - carries its own image with it in potency, and so Christ is never without his image, even before one has actually been produced as an artefact. ${ }^{13}$ A different solution was proposed by Patriarch Nicephorus, who argued that the relation itself (schesis) could survive even when the related things had perished. So, to follow Erismann's reconstruction, suppose someone paints Gregory of Nyssa in his lifetime, then after Gregory has died, the icon ceases, because of the criterion of simultaneity, to be a relative to the model, Gregory, who no longer exists, but none the less the relation itself (of being-an-image) remains. This position is particularly interesting because, elsewhere in these discussions, the Byzantine thinkers stick closely to Aristotle's text in the Categories, where he talks about related things, but not about relations. The idea of relations themselves is a Neoplatonic innovation.

By giving readers a glimpse of how Byzantine thinkers put the analysis of relations to practical use, Erismann raises a wider curiosity about what theoretical accounts of them were developed. Unfortunately, there is no general account available, even a brief one, to let them take their interests further. The theory of relations in Arabic philosophy in general is not much better served. It is clear that in kalām, a type of specifically Islamic philosophical speculation which was influenced only indirectly by Aristotle, there were views about relations strikingly different from those in the Aristotelian tradition - in especial, the tendency to deny relations any reality at all. ${ }^{14}$ Little research has been done on this area, but the views of Avicenna, a critic of the kalām theory, have been subjected to analysis. ${ }^{15}$ Avicenna's discussion is close in some respects (and almost certainly influential on) those of the thirteenth-century Latin thinkers, such as Aquinas and Henry of Ghent who, regarding relations as monadic accidents, try to steer a middle course between taking them as things, and taking them as mental constructs. ${ }^{16}$ But Avicenna himself veers more towards considering relations themselves as purely conceptual.

\footnotetext{
${ }^{13}$ Presumably, in the case of Christ, who has been corporeally resurrected, there will never be lacking the really existing model for the image. Theodore's purpose ('...if, before the image is produced artistically, it subsists always in the prototype: then the veneration of Christ is destroyed by anyone who does not admit that His image is also venerated in Him') seems less to be that of supplying a missing model than to be, as Erismann puts it, 'to associate the relata with each other even more strongly than usual' - for his polemical purposes.

${ }^{14}$ According to Marmura, 'Avicenna's Chapter', 83, the position attacked by Avicenna in the Metaphysics of the Shifä' (III.10. 14-23 according to the divisions of Marmura's complete edition and translation) is put forward by these theologians; cf. Frank, Beings and their Attributes, 99-100, where he describes the Mu'tazilite view that spatial relationship are not states or attributes of any of the atoms which make up reality.

${ }^{15}$ See Zghal, 'La relation chez Avicenne', Bäck, 'Avicenna on Relations' and Lizzini, 'Causality as Relation'.

${ }^{16}$ Cf. Decorte, ‘Avicenna's Ontology of Relation'. Avicenna discusses relations both as part of metaphysics and in his Categories commentary from the Shifā, which, unlike the Metaphysics from this work, was not available in Latin translation. But the Latin writers and Avicenna may have shared a source in Simplicius's Commentary on the Categories, which was translated into Latin by William of Moerbeke in 1266 (see the article by Chase,
} 
Riccardo Strobino's paper is on Avicenna, but it avoids the main themes in the metaphysics of relations which have been discussed by other scholars. Rather, Strobino concentrates on Avicenna's evaluation of relatives when used in demonstrations. That evaluation is a low one. Some demonstrations, Avicenna believes, do not require a causal explanation why such and such is the case, because the major term belongs to the minor, not in virtue of cause, but simply in virtue of the minor term itself. Putative demonstrations involving relative terms might seem to be of this sort, since many relations are not causal, but knowledge of one of the terms of the relation immediately brings knowledge of the other: if someone is a sibling, it can be known immediately that he or she has a sibling. But Avicenna insists that such reasoning is in fact causal, though the causal explanation is hidden. For, as Strobino explains (n. 29), 'the truth of 'Zayd has a brother' is not certain because of the truth of 'Zayd is a brother'. What grounds the certainty is a third thing, like being generated by the same parent.'

Latin Europe before the thirteenth century has been almost as neglected in general surveys of the theory of relations as the Byzantine and Arabic traditions. ${ }^{17}$ Nearly twenty years ago, however, Jeffrey Brower published a study of how the most famous twelfthcentury philosopher, Peter Abelard, conceived relations. Writing in terms heavily influenced by more recent and contemporary debates, Brower concluded that for Abelard 'relations are internal and, for that very reason, reducible to monadic properties of related things' ${ }^{18}$ In his chapter here, Christopher Martin gives a very different view of Abelard's theory, which he scrupulously places in the context of Aristotle's and Boethius's discussions, ${ }^{19}$ and his conclusions accord with a piece published at almost the same time by Christophe Erismann (which should be read together with it, since the two scholars converge in a complementary way, so that each article enriches the other). ${ }^{20}$ As a nominalist, it might be thought that Abelard would wish so far as possible to eliminate relations from his ontology, from considerations of parsimony. Far from it: at least in his logical works, from the earlier part of his career, he not only admits relations as particular forms (for instance, the being-a-father which inheres in John), but holds that, for each child, John has a separate particular form of being-a-father. Abelard's view was not universally held at the time. Martin and Erismann also examine an anonymous commentary (existing in various forms) from roughly the same period, in which it is suggested that being-a-father is a universal accident, individuated only

cited in Martin's article below); cf. Zghal, 'La relation chez Avicenne', n. 33 and Lizzini,'Causality as Relation', n. 91.

${ }^{17}$ A partial exception is found in the work of Kurt Flasch, who attributes to Augustine a 'rehabilitation' of relation (Augustin, 336) and, on the ninth-century thinker, John Scottus Eriugena, see his 'Zur Rehabilitierung der Relation'. On Eriugena, see also Werner Beierwaltes, 'Corrollarium de relatione'.

18 'Abelard's Theory of Relations', 623.

${ }^{19}$ Martin argues (n. 50) that Brower constructs his analysis on a mistaken manuscript reading given in the printed edition of Abelard's logical commentaries.

20 'Paternités multiples'. This article was not available to Martin before he had completed work on his paper. 
by the subject in which it inheres, and so it does not make sense to say that John has more than one form of being-a-father, however numerous his progeny. ${ }^{21}$

Two articles are on the period and setting which has dominated studies of the topic: the Latin universities in the thirteenth and fourteenth centuries. But, whereas most of the existing scholarship has been directed towards the theologians, such Aquinas, Henry of Ghent, Duns Scotus and Ockham, both pieces here are about Arts Masters. Heine Hansen focuses on texts, many of them unpublished, by earlier thirteenth-century Paris Arts Masters, who were working at the time when the full range of Aristotle's texts was just becoming available - in particular, he looks at Robert Kilwardby, who became a master in Paris c. 1237, and would later in life become a Dominican, a theologian and, finally, Archbishop of Canterbury. Hansen, as his title indicates, asks his readers to consider the example (Aristotle's own, though not used by him about relations) of the road from Athens to Thebes. There is just one and the same road from Athens to Thebes, from Thebes to Athens and between Athens and Thebes. Thirteenth-century philosophers, as Hansen shows, considered the position ('instance unicity') that relations are like a road in this way. If Plato is similar to Socrates, then, like the road, there is just one relation (Plato's similarity to Socrates/Socrates's similarity to Plato/ the similarity between Plato and Socrates). Most of the philosophers, however, rejected the position, using various arguments based, especially, on the principle that accidents are individuated by substances and so, since the relation of similarity between Socrates and Plato regards two substances, there will be two particular accidents of similarity. These counter-arguments show how the Aristotelian subject-accident ontology tends to force medieval writers into accounts of relations strikingly different from contemporary ones, although - as Hansen deftly brings out - recent advocates of considering relations as being like the same road between two places fall into difficulties when it comes to asymmetric relations. Moreover, as Hansen's own earlier work has already revealed, there were some thirteenth-century thinkers who argued that relations inhere in a single subject which is made of up of multiple things, and who, he explains, would thus have upheld instance unicity even where the relations are not symmetrical. ${ }^{22}$

The subject of Aurélien Robert's article, John of Jandun, was an Arts Master in Paris in the 1310s, who gained the reputation as a leading Averroist, although in fact in many areas of his thought, including his treatment of relations, he develops positions different from those of Averroes. John was a strong realist with regard to relations. As Schönberger, who provides a very useful survey of his theory as a whole, puts it: 'Not only are there real relations in the sense of their not being dependent on thinking. They are also really distinct from their foundations. ${ }^{23}$ Robert focuses on the question of relations and 'mere Cambridge changes'. What ontological account should be given of a relation which something gains without itself

\footnotetext{
${ }^{21}$ Martin, as opposed to Erismann, stresses that this conclusion represents a strange turn in the whole argument, which it is hard to reconcile with the commentator's overall principles. Erismann also discusses another anonymous commentary of the time, which proposes a view close to Abelard's.

${ }^{22}$ See above, n. 9.

${ }^{23}$ Relation als Vergleich, 181 (see 174-82 for the whole discussion of John). Robert himself does not refer to Schönberger's account.
} 
changing - as when Socrates, who is six-foot-tall and fully-grown, becomes equal in height to Plato, when Plato, who is still growing, reaches six foot? Aquinas was happy in such cases to consider that, whereas Plato acquires a real relation of equality in height to Socrates through the change which makes him, finally, six-foot-tall, the new relation of equality in height which Socrates thereby also acquires without any change is a mere relation of reason. John, however, held that relations of reason could hold only between things of reason concepts - and so that Socrates's newly acquired relation must be real. He removed the paradox of how Socrates could acquire a new accident of relation without any change by arguing that there is a change to him - precisely that of coming to be equal in height to Plato, but it is not the ordinary sort of continuous and divisible change, by which, for example, Plato has gradually turned from being a five-foot-tall boy to a six-foot man, but rather an instantaneous and indivisible change, such as takes place when the sun illuminates the air. Robert's investigation into the ramifications of this position yields some important conclusions. Most interesting of all, Robert suggests that John 'seems to defend what we would call nowadays a theory of property supervenience' about moral virtues, sense perceptions and intellectual knowledge in respect of physical processes; and that the supervenience in question is strong: that is to say, there is a necessary relation between the supervening properties and the supervenience base. ${ }^{24}$ But, he adds, there are important differences from the contemporary notion of supervenience, since John thinks of the supervening properties as the ends and perfections of the physical processes on which they supervene, and that they involve the actualization of a natural potency already present in the subject.

Although historians have tended to neglect fifteenth and early sixteenth-century university thought, much of it is highly sophisticated and some strikingly original. Paloma Pérez-Ilzarbe writes about Hieronymus Pardo, an Arts Master in the circle of John Major at Paris University, who died in 1505, before he could complete his theology degree. PérezIlzarbe studies what seems to be a merely incidental use of relations in semantic theory, but it is one which in fact raises some important ideas for the metaphysics of relations. From the time of Abelard onwards, philosophers discussed whether, just as categorematic words, such as 'Socrates', 'running', 'white' and 'house' in 'Socrates is running to the white house' each have things in the world which they signify, so the sentence as a whole needs a special object to signify. In the fourteenth century, opinion was divided between Buridan and his followers, who insisted that nothing more was required than the objects signified by the individual categorematic terms, and those who held that sentences as a whole signify complexe significabilia (complexly signifiable things). Complexe significabilia are considered to be sui generis entities, and their proponents often tried to making the ontologies they had so burdened seem less encumbered by reducing so far as possible the degree to which the complexe significabilia are entities at all. Pardo is a follower of Buridan, but one who thinks that sentences do need their own significates. He tries to fast along with parsimonious Buridan and yet eat his ontological cake by claiming that these significates are not things, but modes. They are how things are or, more precisely, how things are related to each other: 'a

\footnotetext{
${ }^{24}$ See below, p. [last page of article].
} 
way of standing with respect to ...' Pérez-Ilzarbe argues that by using relations, Pardo introduces an 'intensional' point of view: a mode (which Pardo conceives as a relation) 'belongs to reality, without strictly being a component of the world'. Whatever the ultimate coherence of these metaphysical claims, Pardo's theory has an important consequence which Pérez-Ilzarbe does not consider. Since what is signified by true sentences - that is to say, the facts of the world including all the statements of science - are relations, then these relations, although not considered to be things, are the very foundation of reality: they make the world what it is.

\section{The Logic of Relations}

From ' $\mathrm{A}$ is equal to $\mathrm{B}$ ' and ' $\mathrm{B}$ is equal to $\mathrm{C}$ ' it seems obviously to follow that $\mathrm{A}$ is equal to $\mathrm{C}$. But this conclusion does not follow according to the laws of Aristotelian syllogistic; nor do these laws allow the inference that man is an animal, therefore the head of a man is the head of an animal. ${ }^{25}$ There have been logicians from the time of Alexander of Aphrodisias who have tried to find a way of explaining such reasoning, but general histories of medieval logic leave relational syllogisms out of the picture. ${ }^{26}$ Yet, as was pointed out by Paul Thom nearly 40 years ago, fourteenth-century logicians developed a theory of oblique syllogisms - those in which there is a term in a grammatical case other than the nominative. Many oblique syllogisms are what would now be called relational syllogisms. More recently, Terence Parsons has argued that medieval logic contained the resources to handle relational inferences. ${ }^{27}$ Meanwhile, specialized studies of logicians in the seventeenth century, such as Jungius (1587-1657) and Caramuel y Lobkowitz (1606-82), have shown that they began to explore the logic of relations. ${ }^{28}$ Jungius finds a place for inferences such as 'All circles are figures, therefore whoever draws a circle, draws a figure', whilst Caramuel gave an original analysis of propositions in a relational syllogism. They have a special sort of complex copula, which specifies the relation: for example, 'Ferdinand is a prince appreciated by the people' has as its copula 'is a prince appreciated by the people. Charles Manekin (The Logic of Gersonides) has pointed out the early fourteenth-century Jewish philosopher, Gersonides, explicitly developed a way of making relational inferences. And, in a remarkable book, Relational Syllogisms and the History of Arabic Logic, 900-1900, Khaled el-Rouayheb has uncovered a whole tradition of sophisticated development of relational syllogistic in the Arabic tradition, especially in the eighteenth century and later.

\footnotetext{
${ }^{25}$ The second example is De Morgan's (Formal Logic, 114; cited by Parsons, Articulating Medieval logic, 161).

${ }^{26}$ The Kneales (The Development of Logic, 259) suggest in passing that Ockham and his contemporaries 'had begun to work out some of the details ... for the ... theory of relations', but do not elaborate. The Cambridge History of Later Medieval Philosophy, despite its very full treatment of logic, mentions the logic of relations only once (796), as an example of an area where the medieval logicians failed; and there is nothing on the logic of relations in the current Cambridge History of Medieval Philosophy. In Haaparanta's more recent collection on The Development of Modern Logic, similarly, the chapter on later medieval logic (by Mikko Yrjönsuuri) says nothing about the logic of relations. Only in the chapter on Caramuel are relations discussed in the medieval volume of Gabbay and Woods's Handbook of the History of Logic.

${ }^{27}$ Articulating Medieval Logic, 160-63.

${ }^{28}$ See Ashworth 'Joachim Jungius' and Dvořák, 'Relational Logic of Juan Caramuel'.
} 
From these studies, it might seem that historians are starting to find that there were at least the beginnings of a logic of relations in the medieval Aristotelian tradition. Massimo Mugnai's article is especially important, because it is the first explicit, general discussion of this topic. Mugnai's conclusion, however, is negative. Taking up Thom's investigation of the treatment of oblique terms by fourteenth-century logicians such as Ockham and Buridan, he argues that the relational syllogisms they propose are valid because of the laws which apply to other types of syllogisms too, rather than by virtue of the properties of the relations concerned. Mugnai is also sceptical about the success of the various seventeenth-century attempts to devise a logic of relations. He gives a special place to Caramuel, but finds his logica obliqua vague and lacking in systematic rigour. His comments add a valuable element of scepticism to the search for a medieval logic of relations, but they leave it open for the champions of Caramuel or the later Arab logicians to argue that his assessment is too harsh, and that these logicians in the medieval tradition may have succeeded in constructing a partial logic of relations even if they did not follow the path which would later be indicated by De Morgan.

Mugnai also offers an explanation for why medieval thinkers did not go very far towards a logic of relations. He points to the characteristic feature of most medieval theories about the ontology of relations: the denial that one relation can exist in both of the related things - that there are 'polyadic properties'. Had they acknowledged the existence, or even 'pragmatically, the usefulness' of such properties, then it would have been much easier, so Mugnai contends, for them to develop a logic of relations.

\section{Some Suggestions for the Future}

This sketch of how relations in medieval philosophy have been discussed, and how they are addressed in the specialist articles collected here, suggests some conclusions which bear, not just on this topic, but more generally. They concern (1) the chronological and geographical range of medieval philosophy, (2) its relation to theology and (3) its relation to philosophical thinking today.

(1) This collection aims especially to show how a single medieval tradition of treating relations is found in its various different branches (Greek, Latin and Arabic), and from the time of Boethius, at the turn of the sixth century, to late in the seventeenth. But a single volume can, on its own, do only a limited amount to right the bias towards Christian Latin thinkers of the thirteenth and early fourteenth centuries which is common throughout the subject and very strikingly evident in the case of this particular topic. Those looking for a general orientation will find themselves directed towards a small and fairly homogeneous group of thinkers - Aquinas, Henry of Ghent, Duns Scotus, Henry of Harclay, Peter Aureol, William of Ockham: all of them theologians at Paris or Oxford in the hundred years from 1250. Even outliers within the broad Latin later medieval tradition (non-theologians, those 
outside the universities) are hardly mentioned, and the Greek, Arabic and Jewish traditions even less. ${ }^{29}$ As a result, we should admit that, at the moment, we know too little to form any definite conclusions about medieval thought on relations, and we should be willing to shift the emphasis of research away from the one patch within this wide field that is relatively well studied to the mass of texts from many centuries and in various languages which have not yet been examined in connections with this topic.

(2) There is another, completely different aspect of the breadth of medieval discussion about relations (and most other concepts). Relations were not merely a philosophical, but also a theological topic. Indeed, as will already be clear, in the Latin tradition most of the theories that have been investigated were the work of theologians. The links between theories of relations and theology are not, however, much evident in the essays here (except for Erismann's piece on the controversy over icons in Byzantium). Nor indeed are they to the forefront in the wider literature: although the central authors treated are usually theologians, their views about relations tend to be treated as if they were purely philosophical. The implications of Aristotelian ontology are freely acknowledged, but those of Christian (or Jewish, or Muslim) doctrine tend to be ignored. Yet both contributed to shaping the medieval debate and, if they constrained it in ways some might find regrettable, in other ways they added to its richness.

The theological element becomes particularly fascinating if it is studied in the light of all the four major branches of the tradition from a comparative perspective - something that has not yet been done. As already mentioned, Jews, Christians and Muslims all needed to explain how creatures could be related to God, without positing any changing accidents of relation in the immutable divinity. But Christians, unlike Jews and Muslims, also believed that God, as Father, Son and Holy Spirit, is himself relational, and so, however much they followed Aristotelian ontology, they could not accept that relation is in all cases a type of accident. How did what their religious doctrines had in common, and where they differed, affect the ways in which thinkers of different faiths developed, distorted or, to some extent, emancipated themselves from the Aristotelian heritage?

(3) The articles here, as already noted, follow the Standard Historical Method. Some of the writers choose simply to explain the medieval texts just in their own terms, but others include incidental or more extensive (Hansen) comparison with contemporary discussions, or implicitly take their starting point from them (Mugnai). Although none of them uses today's theories as an explicit measure of how earlier views went wrong, in the way Weinberg did, they treat them as setting a norm, from which the medieval theories are deviations. For example, Robert refers to the notion of supervenience, but points out various ways in which John of Jandun's assumptions differ from those of philosophers who use this idea today. And most of the writers regard the usual contemporary view that relations are polyadic properties as clear and obvious, and the medieval view that they are monadic as in need of explanation.

\footnotetext{
${ }^{29}$ Two important outliers, who arguable give more attention to relations than most medieval philosophers, are Ramon Llull (cf. Flasch, Das philosophische Denken, 446-47) and Nicholas of Cusa (see Kampits, 'Substanz und Relation bei Nicolaus Cusanus').
} 
In many cases, however, the contemporary views are no more clear and obvious, and no less contestable, than the medieval ones. For example, both the definition of supervenience and its explanatory value are now debated. With regard to polyadic properties, it is open to ask whether this notion is an informative one. The terms 'monadic' and 'polyadic' apply literally to expressions in language. If their use to describe properties is merely metonymous, so that a polyadic property is just the sort of property signified by a polyadic expression, then relations will be polyadic according to the standard Aristotelian and medieval theory, since it recognized that relations are signified by multi-place expressions (for instance, '---is the father ---'). And, if properties are held literally to be polyadic, what can this mean? How can an abstract entity have two or more places or slots? To answer that for a property to be polyadic means that it relates two or more things would be merely to explain what relations are by saying that they are relations. It is indeed true that arguments have been brought forward, for instance by Bertrand Russell, against the coherence of a theory of relations founded on ordinary (monadic) accidents. But counter-arguments can, and have, been proposed; the Aristotelian outlook on relations remains defensible. ${ }^{30}$

This comment should not be taken to imply that the main value for investigation into medieval (or other historical) treatments of a topic such as relations lies in how it can help contemporary philosophical discussion. On the contrary, its point is to suggest how historians of philosophy can best make use of contemporary debates for their own historical ends. Where contemporary philosophy is treated too reverentially, as a fixed body of doctrine that sets up a standard against which earlier philosophers must be judged, it may indeed have the value of making strange assumptions that specialists' immersion in their chosen period have rendered, on a superficial level, too familiar. But it is only when the historians come to engage with today's discussions as philosophy - as arguments and ideas open to attack and refutation - that they can use them to help engage with the historical texts as philosophy too, and so strive to make familiar what, on a deeper level, remains strange about them even to the consummate specialist. ${ }^{31}$

\section{John Marenbon}

\footnotetext{
${ }^{30}$ See Anna Marmodoro's comments in the Introduction to The Metaphysics of Relations (3-7). For Russell's criticisms, see The Philosophy of Mathematics I, 221-26 (sections 212-16) and cf. Candlish, The Russell/Bradley Dispute, especially chapter 6.

${ }^{31}$ Novalis's idea of making the strange familiar and vice versa was used by Bernard Williams ('Descartes and Historiography', 259), but - conversely to what I suggest here - as a way of explaining the value of history of philosophy to contemporary philosophy. I am grateful to Mike Beaney, Christophe Erismann, Tony Street, Riccardo Strobino and Sophia Vasalou for bibliographical help with this Introduction, and to Anna Marmodoro for reading it through before publication.
} 


\section{BIBLIOGRAPHY}

Adams, Marilyn McCord. William Ockham I, Notre Dame: University of Notre Dame Press, 1987 (Publications in Medieval Studies, 26/1).

Ashworth, E. J. 'Joachim Jungius (1587-1657) and the Logic of Relations', Archiv für Geschichte der Philosophie 49 (1967), 72-85.

Avicenna, The Metaphysics of The Healing, ed. and trans. MIchael Marmura, Provo: Brigham University Press.

Bäck, Allen. 'Avicenna on Relations and the Bradleyan Regress' in La Tradition médiévale des Catégories (XIIe - Xve siècles), ed. Joël Board and Irène Rosier-Catach, Louvain-laneuve, and Louvain, Paris and Dudley: Éditions de l'Institut Supérieur de Philosophie and Éditions Peeters, 2003 (Philosophes médiévaux 45), 69-84.

Bäck, Allen. Aristotle's Theory of Abstraction, Cham, Heidelberg, New York, Dordrecht and London: Springer, 2014 (New Synthese Historical Library 73).

Beierwaltes, Werner. 'Corollarium de relatione' in Werner Beierwaltes, Eriugena.

Grundzüge seines Denkens. Frankfurt am Main: Klostermann, 1994, 256-61.

Brower, Jeffrey. 'Abelard's Theory of Relations: reductionism and the Aristotelian tradition', The Review of Metaphysics 51 (1998), 605-31.

Brower, Jeffrey. 'Medieval Theories of Relations' in The Stanford Encyclopedia of Philosophy (Winter 2015 Edition), ed. Edward Zalta (ed.), URL = <http://plato.stanford.edu/archives/win2015/entries/relations-medieval/>.

Brower, Jeffrey. 'Aristotelian vs Contemporary Perspectives on Relations' in Marmodoro and Yates, The Metaphysics of Relations, 36-54

Candlish, Stewart. The Russell/Bradley Dispute and its Significance for Twentieth Century Philosophy, Basingstoke: Palgrave Macmillan, 2007.

Cesalli, Laurent. 'Relation' in Dictionnaire du Moyen Âge,ed. Claude Gauvrard, Alain de Libera and Michel Zink, Paris: Presses Universitaires de France, 2002, 1194-96.

Decorte, Jos. 'Avicenna's Ontology of Relation: A Source of Inspiration to Henry of Ghent' in Avicenna and His Heritage, ed. Jules Janssens and Daniël De Smet, Leuven: Leuven University Press, 2002, 171-196.

De Morgan, Augustus. Formal Logic: or The Calculus of Inference, Necessary and Probable, London: Taylor and Walton, 1847.

Dvořák, Petr. 'The Relational Logic of Juan Caramuel' in Gabbay and Woods, Handbook, 645-65. 
Ebbesen, Sten. 'Tantum Unum Est. $13^{\text {th }}$-century sophismatic discussions around the Parmenidean thesis', The Modern Schoolman 72 (1995), 175-99.

Ebbesen, Sten. 'The Paris Arts Faculty: Siger of Brabant, Boethius of Dacia, Radulphus Brito' in Medieval Philosophy (Routledge History of Philosophy III), ed. John Marenbon. London and New York: Routledge, 1998.

El-Rouyaheb, Khaled. Relational Syllogisms and the History of Arabic Logic, 900-1900. Leiden and Boston: Brill, 2010 (Islamic Philosophy, Theology and Science. Texts and Studies 80).

Erismann, Christophe. 'Paternités multiples. Les débats sur les relatifs entre Anselme et Abélard', Medioevo 39 (2014), 11-29.

Flasch, Kurt. 'Zur Rehabilitierung der Relation. Die Theorie der Beziehung bei Johannes Eriugena' in Philosophie als Beziehungswissenschaft, ed. Wilhelm Niebel and Dieter Leisegang, Frankfurt: Heiderhof, 1974, 3-25.

Flasch, Kurt. Das philosophische Denken im Mittelalter. Von Augustin zu Machiavelli. Stuttgart: Reclam, 2000 ( $2^{\text {nd }}$ edition).

Flasch, Kurt. Augustin. Einführung in sein Denken, Stuttgart: Reclam, 2003 ( $3^{\text {rd }}$ edition).

Frank, Richard. Beings and their Attributes. The teaching of the Basrian School of the Mu'tazila in the Classical Period, Albany: State University of New York Press, 1978.

Gabbay, Dov and John Woods (eds). Handbook of the History of Logic 2. Mediaeval and Renaissance Logic (Amsterdam: North Holland).

Haaparanta, Leila (ed.). The Development of Modern Logic. New York: Oxford University Press, 2009.

Hansen, Heine. 'Strange Finds, or Nicholas of Paris on Relations' in Logic and Language in the Middle Ages. A volume in honour of Sten Ebbesen, ed. Jakob Fink, Heine Hansen and Ana María Mora-Márquez. Leiden and Boston: Brill, 2013, 139-54 (Investigating Medieval Philosophy 4).

Henninger, Mark G. Relations. Medieval theories 1250-1325. Oxford: Oxford University Press, 1989.

Kampits, Peter. 'Substanz und Relation bei Nicolaus Cusanus', Zeitschrift für philosophische Forschung 30 (1976), 31-50.

King, Peter. 'Scotus on Metaphysics' in The Cambridge Companion to Duns Scotus, ed. Thomas Williams. Cambridge: Cambridge University Press, 2003, 15-68.

Kneale, William and Martha, The Development of Logic, Oxford: Oxford University Press, 1962. 
Krempel, A. La doctrine de la relation chez Saint Thomas. Exposé historique et systématique. Paris: Vrin, 1952.

Kretzmann, Normann, Anthony Kenny and Jan Pinborg (eds). The Cambridge History of Later Medieval Philosophy, Cambridge: Cambridge University Press, 1982.

Lizzini, Olga. 'Causality as Relation: Avicenna (and al-Ġazālī)', Quaestio 13 (2013), 165-95.

Manekin, Charles. The Logic of Gersonides. A translation of Sefer ha-Heqqesh ha-Yashar (The Book of Correct Syllogism) of Rabbi Levi ben Gershom. Dordrecht, Boston and London: Kluwer, 1992 (The New Synthese Historical Library 40).

Marenbon, John. Medieval Philosophy. A very short introduction, Oxford: Oxford University Press, 2016.

Marenbon, John and Strobino, Riccardo. 'Congrès terminés. 4 Cambridge: 'Medieval Theories of Relations', Bulletin de Philosophie Médiévale 56 (2014), 435-48.

Marmodoro, Anna and Yates, David (eds). The Metaphysics of Relations, Oxford: Oxford University Press, 2016.

Marmura, Michael. 'Avicenna's Chapter, 'On the Relative', in the Metaphysics of the Shifä', in essays on Islamic Philosophy and Science, ed. George Hourani, Albany: State University of New York Press, 1975, 83-99.

Mojsisch, Burkhard. 'Relation. Spätantike, Mittelalter und Renaissance' in Historisches Wörterbuch der Philosophie, 8, Wissenschafltiche Buchgesellschaft: Dortmund, 1992, 58695.

Parsons, Terence. Articulating Medieval Logic, Oxford: Oxford University Press, 2014.

Penner, Sydney. 'Why do Medieval Philosophers reject Polyadic Accidents?' in in Marmodoro and Yates, The Metaphysics of Relations, 55-79.

Porro, Pasquale and Carraud, Vincent (eds). The Ontology of Relation = Quaestio 13 (2013).

Russell, Bertrand. The Principles of Mathematics. Cambridge: Cambridge University Press, 1903.

Schonberger, Ralph. Relation als Vergleich. Die Relationstheorie des Johannes Buridan im Kontext seines Denkens und der Scholastik. Leiden, New York and Cologne: Brill, 1994 (Studien und Texte zur Geistesgeschichte des Mittelalters 43).

Suárez, Francisco. Disputationes Metaphysicae, Hildesheim: Olms, 1965.

Thom, Paul. 'Termini Obliqui and the Logic of Relations', Archiv für Geschichte der Philosophie 59 (1957), 143-55.

Weinberg, Julius R. Abstraction, Relation, and Induction. Three essays in the history of thought. Madison and Milwaukee: the University of Wisconsin Press, 1965. 
Williams, Bernard. 'Descartes and the Historiography of Philosophy' in Williams, The Sense of the Past, Princeton: Princeton University Press, 1994, 257-64.

Zghal, Hatem. 'La Relation chez Avicenne', Arabic Sciences and Philosophy 16 (2006), 23786. 